\title{
Measurement of Wear Metals in Engine Oils by Atomic Absorption Spektrometry Method
}

Vladimír Hönig, Daniela Miholová, Matyáš Orsák

Faculty of Agrobiology, Food and Natural Resources, Department of Chemistry, Czech University of Life Sciences Prague. Kamýcká 129, 16521 Prague 6 - Suchdol. Czech Republic. E-mail: honig@af.czu.cz, miholova@af.czu.cz, orsak@af.czu.cz

The article describes a method of measuring engine oil wear metals by Atomic Absorption Spectrometry (AAS), which is an analytical method used to determine the concentrations of various elements in the sample. Atoms of different elements absorb different wavelengths of light in proportion to the quantities in which they are represented, as an analytical measurement property is performing absorption of radiation by free atoms of the reference element. AAS method with flame atomization allows measuring the concentration of about 60 elements of the periodic table in a solution with a sensitivity from hundredths to hundred $\mu \mathrm{g} \cdot \mathrm{ml}^{-1}$. It is used in the analysis of samples of different origins. This method makes up a significant part of monitoring low levels of toxic elements in environmental samples, which is very good to be used for its high sensitivity and selectivity. The aim of the study was the evaluation of the composition of wear particles tested oil samples by AAS, which is highly accurate and a fully automated tribotechnical diagnostics method. The intensity of each line radiation gives information about the content of investigated metals in the tested samples of motor oils, which enable us to identify not only the place from which abrasion arises, but also reveals the cause of the critical condition of the mechanism.

Keywords: Atomic Absorption Spectrometry, Absorbance, Engine Oil, Wear Particles, Tribotechnical Diagnosis

\section{References}

[1] ALEŠ, Z., PEXA, M., PAVLUீ, J. (2012). Tribotechnical diagnostics of agricultural machines, Engineering for Rural Development conference Jelgava, 24.-25.05.2012, [online]. [cit.2014-05.01] Available at www: http://www. http://tf.llu.lv.

[2] ALEŠ, Z. (2010). Field experience with transmission oil EP Gear Synth 150, Research in Agricultural Engineering, Vol. 55, pp.18-23. Czech Academy of Agricultural Sciences. Prague. Czech Republic.

[3] CELEBRANT, F., ZIEGLER, J., MARASOVÁ, D. (1996). Technická diagnostika a spolehlivost I. Tribodiagnostika. 1. vydání. pp. 110 - 138. VŠB-TU, Ostrava, Czech Republic

[4] FOSTER, L.H., SUMAR, S. (1996). Hydride generation atomic absorption spectrometric (HGAAS) determination of selenium in term and preterm infant formulae available in the United Kingdom, Food Chemistry, Vol. 55, No. 3, pp. 293 - 298. Elsevier Limited. United Kingdom.

[5] HÖNIG, V., HROMÁDKO, J. (2014). Possibilities of using vegetable oil to power diesel engines as well as their impact on engine oil, Agronomy Research Vol. 12, No. 8, pp. 323 - 332. Estonian Agricultural University. Estonia.

[6] SZÁKOVÁ, J., KOLIHOVÁ, D., MIHOLOVÁ, D., MADER, P. (2004). Single- purpose atomic absorption spectrometer AMA-254 for mercurydetermination and its performance in analysis of agricultural andenvironmental materials. Chemical Papers, Vol. 58, No. 5, pp. 311 - 315. Versita, United Kingdom.

[7] SPĚVÁČKOVÁ, V., KNOTKOVÁ, J. (1998). Prvková analýza klinických materiálu - aplikace elektrotermické atomové absorbční spektrometrie, Chemické listy Vol. 92, pp. 287 - 293. Czech Society of Chemical Engineering, Prague, Czech Republic.

[8] TINGGI, U., REILLY, C., PATTERSON, C. (1997). Determination of manganese and chromium in foods by atomic absorption spectrometry after wet digestion, Food Chemistry, Vol. 60, No. 1, pp. 123 - 128. Elsevier Limited. United Kingdom. 